\title{
RESEARCH
}

Open Access

\section{Ethnobotanical survey of wild edible plants used by Baka people in southeastern Cameroon}

\author{
Pascal Eric Billong Fils ${ }^{1}$, Natacha Afiong Nana ${ }^{1}$, Jean Lagarde Betti ${ }^{1}$, Oumar Farick Njimbam', \\ Stéphanie Tientcheu Womeni ${ }^{1}$, Eva Ávila Martin ${ }^{2}$, Guillermo Ros Brull2 ${ }^{2}$ Robert Okale ${ }^{2}$, Julia E. Fa ${ }^{3,4}$ and \\ Stephan M. Funk ${ }^{5^{*}}$ (D)
}

\begin{abstract}
Background: Forest inhabitants worldwide, and indigenous people especially, have depended for generations on plants and animals harvested in these ecosystems. A number of Baka hunter-gatherer populations in south-eastern Cameroon became sedentarised in the 1950s, but still rely on hunting and gathering to meet their basic needs. The use of wild edible plants (WEP) by these communities remains largely undocumented. In this study, we record the diversity of WEP used by Baka people in dense rainforests in the Mintom region. The area still contains relatively undisturbed forest expanses, just south of the Dja Biosphere Reserve, one of the most important protected areas in the Congo Basin.
\end{abstract}

Methods: We conducted two ethnobotanical surveys in 2019 in four villages on the Mintom road. In the first survey, we interviewed a total of 73 individuals to determine WEP usage. In our second survey, we specifically quantified WEP harvested and consumed daily in a number of households over a 2-week period during the major rainy season, when use of forest products is highest. Specimens of all recorded plants were collected and identified at the National Herbarium of Cameroon.

Results: We documented 88 plant species and 119 unique species/plant organ/recipes in 1519 different citations. A total of 61 genera and 43 families were noted. Excluding 14 unidentified wild yam species, 17 WEP species had not been reported in previous ethnobotanical surveys of the Baka. Our results showed that cultivated starchy plant foods make up a significant proportion of our study population's daily nutritional intake.

Conclusions: A high diversity of WEP is consumed by the studied Baka communities. The study area is likely to be significant in terms of WEP diversity since 18 out of the 30 "key" non-timber forest products, NTFP, in Cameroon were mentioned. Documentation of the use of WEP by indigenous communities is vital to ensure the continuity of traditional knowledge and future food security.

Keywords: Dja biosphere reserve, Wild edible plants, Ethnobotany, Diversity indexes, Baka people, Hunter-gatherer, Africa, Food security

\footnotetext{
* Correspondence: smf@natureheritage.org

${ }^{5}$ Nature Heritage, St. Lawrence, Jersey, Channel Islands, UK

Full list of author information is available at the end of the article
}

\section{$\triangle B M C$}

(c) The Author(s). 2020 Open Access This article is licensed under a Creative Commons Attribution 4.0 International License, which permits use, sharing, adaptation, distribution and reproduction in any medium or format, as long as you give appropriate credit to the original author(s) and the source, provide a link to the Creative Commons licence, and indicate if changes were made. The images or other third party material in this article are included in the article's Creative Commons licence, unless indicated otherwise in a credit line to the material. If material is not included in the article's Creative Commons licence and your intended use is not permitted by statutory regulation or exceeds the permitted use, you will need to obtain permission directly from the copyright holder. To view a copy of this licence, visit http://creativecommons.org/licenses/by/4.0/ The Creative Commons Public Domain Dedication waiver (http://creativecommons.org/publicdomain/zero/1.0/) applies to the data made available in this article, unless otherwise stated in a credit line to the data. 


\section{Background}

In tropical forests throughout the globe, wild edible plants (WEP) and fungi have great cultural significance as well as conferring nutritional benefits for myriad indigenous farming and hunter-gatherer communities [1]. These foods provide a variety of macro- and micronutrients across different seasons and ecological zones [2], but can also be important famine foods [3, 4]. Some WEP plays a symbolic link between nature and society for those communities who use them. African huntergatherer populations consider yam tubers to have a connection between elephants and their tutelary spirit "jengi," since wild yams are a fundamental plant food for Pygmies and elephants-elephant hunting is traditional in these indigenous groups [5].

The diet of indigenous peoples in general, and huntergatherers in particular, are rapidly changing [6]. Currently, almost no hunter-gatherer population relies solely on wild foods, consuming a mixed diet that includes farmed foods, and in some cases diets that are subsidized by governments and aid organizations [7]. Reyes-García et al. [8] reported that Baka Pygmies living in or near market towns in Cameroon had a lower dietary diversity and consumed more sugar than those living more remotely whose diets contained more WEP and were more balanced in micronutrients. After sedentarization from the 1950s onwards, Baka who supplemented their life in the village with time in forest camps exhibited reduced stress levels helping them maintain a better nutritional status overall [9].

Market economies impact the lifestyle of huntergatherers, often by increasing their reliance on cultivated starchy staple foods and decreasing the use of WEP, eroding traditional local knowledge on how to find, identify, and process these plants. For example, only a few Baka elders still mastered the preparation of African oil bean (Pentaclethra macrophylla) seeds, which require several days soaking in running water to eliminate toxic compounds [10]. Bahuchet et al. [11] suspected that knowledge of the use of some WEP has already completely disappeared. Gallois et al. [10] documented how the high valuation of cultivated and commercial foods has changed the vocabulary used by the Baka to describe wild foods. The bark of Afrostyrax lepidophyllus is now known as "[bouillon] cubes of the forest" to the Baka, reflecting that bouillon cubes are, together with salt, the most bought dietary item by these communities when opportunities arise. In parallel to these social changes, the environment is being degraded at an unprecedented scale. Between 2000 and 2014, 16.6 million hectares of rainforest were lost in the Congo Basin, most (84\%) from small-scale, nonmechanized forest clearing for agriculture, alongside selective logging [12].
Few studies have cataloged and investigated the use of WEP among hunter-gatherers in the Congo Basin. Hunter-gatherers are known for their extensive knowledge of plants used for medicine, food, and their material culture; as many as 24 plants $(77 \%)$ used by BaYaka hunter-gatherers from Congo have bioactive properties and some are positively associated with children's BMI [13]. Studies on general plant use have been conducted among hunter-gatherers but most focus on medicinal plants rather than WEP. Studies on WEP have concentrated on wild yam tubers because of their importance for understanding the colonization of the rainforest by hunter-gatherer populations [14-18]. Only Tanno [19] for the Mbuti and Gallois et al. [10] and Betti et al. [2022] for the Baka have investigated the broad spectrum of use of WEP. Hattori [23] detailed the use of Marantaceae plants as non-timber forest products, NTFP, two of which (Haumania danckelmaniana, Trachyphrynium braunianum) are seeds consumed by the Baka.

Hunter-gatherer people are distributed throughout the Congo basin in Africa. They conform several genetically and ethno-linguistically distinct groups [24], broadly subdivided into western groups such as the Baka and Aka, and eastern groups comprising the Efe and Asua. All live mainly in tropical rainforests as forest foragers and hunter-gatherers although two groups, the Bedzan (Medzan) of Cameroon and the Twa of Rwanda and Burundi, inhabit non-forest areas [25]. Although the preeminent traditional way of life for these groups remains associated with forest hunting and gathering, most contemporary groups have taken up some form of agriculture. A typical example are the Baka of the western Congo basin who are distributed in four different countries with the majority living in Cameroon, numbering about 40,000 individuals [26]. Since the 1950s, Baka became sedentarised following missionary activities and the "development assistance" programs by the State after independence $[11,26]$; the adoption of agriculture and semi-sedentary lifestyle has been mostly voluntary [27].

Documenting the types of plants used by indigenous people is becoming more urgent as these communities change away from natural diets containing WEP toward domesticated cultigens and processed foods. In this paper, we document WEP use by sedentarised Baka communities in the Mintom region in Cameroon, recording the different usage, and quantifying daily amounts consumed.

\section{Methods}

\section{Study site}

The study region is located in the eastern part of the Division of Dja et Lobo in south-eastern Cameroon, south of the Dja Faunal Reserve, and the Dja Biosphere Reserve (Fig. 1). Four study villages were 
selected near the provincial capital Mintom. Mintom has about 6000 inhabitants and is located about $30 \mathrm{~km}$ South of the Dja Reserve and $300 \mathrm{~km}$ east of the State capital Yaoundé: Assok (15 km East of Mintom), Bemba II and Abing-Nkolemboula (20 and $15 \mathrm{~km}$ north, respectively), and Doum (8 km west). Population censuses conducted by us recorded 76 inhabitants in Assok, 62 in Bemba II, 59 in Abing-Nkolemboula, and 109 in Doum during the study period. These villages are predominantly Baka. Interspersed between a total of about 30 Baka villages are about 50 villages exclusively inhabited by major ethnic communities part of the Bantu language group.

Hunter-gatherer groups have witnessed the gradual reduction of access to forest resources [28]. After relocation from the forest, Baka have opened their own plots to grow subsistence crops such as plantain, banana, and cassava [29]. This change in lifestyle has been associated with a marked decline in physical and mental health [30]. Farming has increased in recent years in our study villages, particularly as a result of agricultural programs initiated by our study partner Zerca y Lejos (ZyL) [31, 32], a Spanish NGO working on development and providing health support to Baka communities in the region. Supplementing their life in the village with time in forest camps has led to reduced stress and has helped them maintain better nutritional status [9]. Hunting, fishing, and gathering depend on both the agricultural timetable and season [33].

The climate is equatorial and humid. Rainfall averages between 1500 and $2000 \mathrm{~mm}$ per year, and some precipitation is common even during the dry seasons [34]. Mean annual temperature is $25^{\circ} \mathrm{C}$, fluctuating slightly between seasons. There are four seasons: a major dry season is from December to March, a minor rainy season from March to May, a minor dry season in August, and a major rainy season from September to November [10]. The terrain of the region is sloping with gently rolling hills ranging between 250 and 800 . The major vegetation type is a mixture of evergreen and semi-deciduous forests [35]. Three broad categories of forests can be distinguished in the Mintom area: forests on rocks, forests on firm soil, and aquatic or hydromorphic forests. Forests on firm soil are divisible into primary and secondary forests.

\section{Data collection}

Ethical approval was not required in this study, although it meets the guidelines of the Social Research

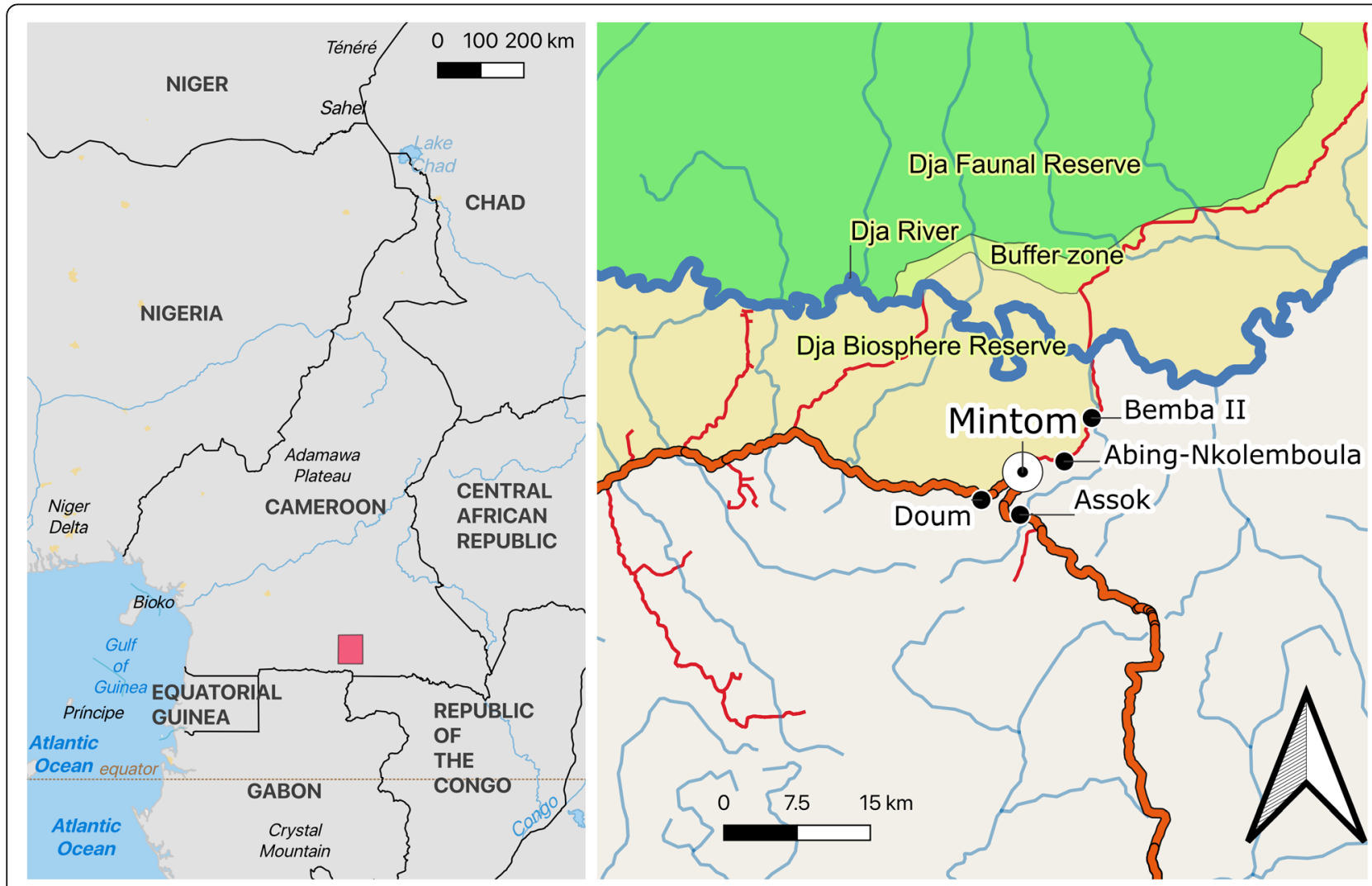

Fig. 1 Map of Cameroon showing the study villages surveyed during the present study. Source: public domain map data from Open Street Map, diva-gis (www.diva-gis.org) and Natural Earth (www.naturalearthdata.com) 
Association [36]. Permission to undertake field work in our study area was granted by the Ministry of Scientific Research and Innovation (MINRESI), via the Center for International Forestry Research (CIFOR) in Cameroon. Authorization to work with human subjects was covered by the Arrete No. 00034/A/MINATD/DAP/SDLP granted by the Ministère de l'Administration Territoriale et de la Décentralisation of the Government of Cameroon to $\mathrm{ZyL}$.

In following the principle of free, prior, and informed consent (FPIC), allowing our study communities to give or withhold consent to our project, the Cameroonian field team first organized a meeting with each village in January 2019. All workshops, undertaken in Fang, the lingua franca between the Baka and the local Bantuspeaking farmers, were led by two members of our team, assisted by three local facilitators. The objectives of the project were presented and the interviewers were introduced to the villagers.

Interviews were conducted between January and March 2019, following a pre-prepared open-ended questionnaire. To facilitate communication with the villagers, each interviewer was assisted by a Baka guide from each village, who spoke both French and the Baka language. The guide verbally translated our questionnaire from French to the Baka language (Additional file). Questions were asked to all members of an interviewed household jointly and every answer was noted. General information was first gathered on name, village, ethnic group, age, and sex of the respondents. Questions related to plant (wild and domesticated) use were "to what extent food usage (mode of use) was associated to which plant species" rather than asking "which plants were used for which food usages." For each mode of use cited (drink, fruit, ingredient, main course, vegetable) we recorded the vernacular Baka name of the plant, plant parts used, the method of harvesting (collecting, cutting, digging), distance from the village for collecting the plant and period of collection during the year. While a "quotation" lists any plant/usage combination by any household irrespective on how often it is cited by different people, "recipes" represent unique species/plant organ/usage combinations. A rarefaction analysis by stepwise addition of informants was conducted to estimate how the addition of informants increased the number of plant species and recipes.

Harvested edible plants, including agricultural plants and WEP, were recorded daily for 14 days between the 22nd of October and the 7th of November 2019 in Assok and Doum. This period encompassed the major rainy season, when mobility into the forest for hunting and gathering is highest among the seasons [10]. Each item destined to be consumed was weighted, and the vernacular names and use were noted.
Plant specimens listed by informants were collected with assistance from the Baka guides. Some plants, mainly trees, were identified in the field but all others were deposited at the National Herbarium of Cameroon (HNC) in Yaoundé. At the $\mathrm{HNC}$, all specimens were first sterilized with alcohol at $90^{\circ} \mathrm{C}$, dried with hot air, and then kept at $20^{\circ} \mathrm{C}$ for 3-4 days and sprayed with insecticides. Specimens were identified to the genus level and, whenever possible, to the species level by comparing them with specimens in the herbarium, local field, and identification guides $[35,37,38]$, and online databases [39-41].

A total of 73 Baka households provided information on the use of WEP and cultivated plants; 18 households in Assok, 23 in Bemba II, 16 in Doum, and 16 in AbingNkolemboula. Information was provided by 21 women $(28.8 \%), 46$ men $(63 \%)$, and 6 couples $(8.2 \%)$, who were between 18 and 80 years old (average 42 years).

\section{Data analysis}

Diversity indices used are those often employed to assess the diversity in systematic botany or forest ecology [42] such as the Shannon-Weaver index [43], the Simpson index [44], and the regularity or the equitability index of Pielou [45]. The Shannon Weaver index $\left(\mathrm{H}^{\prime}\right)$ allows to assess the diversity level of each group taking into account the proportion of each plant in the group. The Simpson index (D) measures the probability for two citations withdrawn randomly from a given group to belong to the same plant or recipe. The regularity or the equitability index of Pielou measures the diversity level reached by a group compared to its maximal level of diversity. It compares two groups which have different number of individuals. An ANOVA was used to compare diversity indices between gender and villages. The amounts of consumed cultivated plants and WEPs was compared with the nonparametric Wilcoxon rank-sum test. Data analysis was performed using R version 3.5.1 [46].

\section{Results \\ Diversity of WEPs}

A total 1519 citations from 88 different plant species were recorded. The plant citations ranged between one and 45 per informant (mean 20.8). We also identified 119 recipes, i.e., unique species/organ/usage combinations. Rarefaction analysis shows that the information collected did not reach a saturation plateau (Fig. 2).

Interviewed women $(n=21)$ reported the use of 69 species and 86 recipes, men $(n=46)$ described 77 species and 100 recipes, and couples $(n=6)$ a total of 51 plants and 59 recipes. Diversity indices (Table 1) indicate an overall high diversity. Average usage densities were 1.2 plants/informant and 1.6 recipes/informant. Values were highest among couples, high for women alone, and 


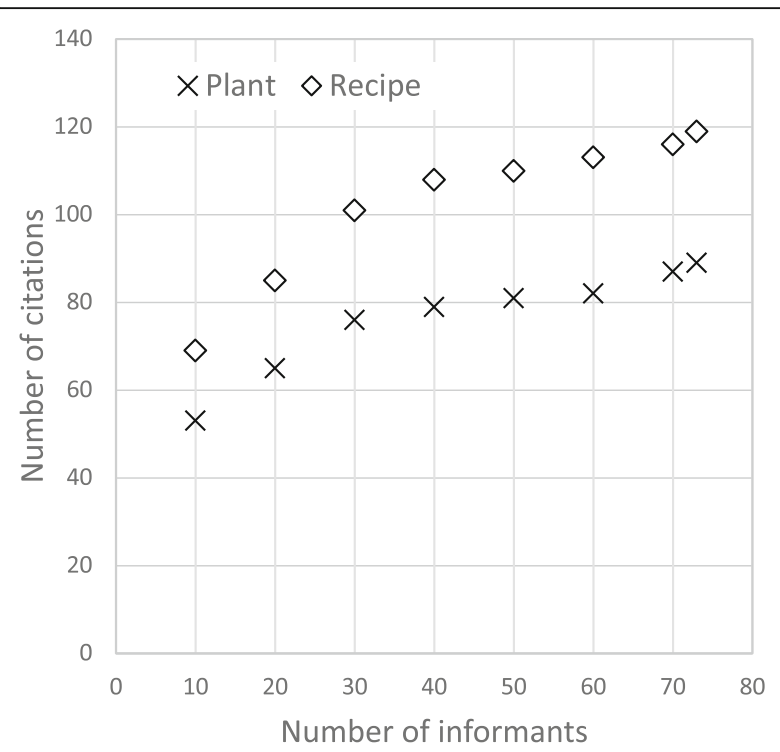

Fig. 2 Rarefaction analysis for the number of citations (plants and recipes, i.e., unique combinations of organs of species and their use) dependent of the number of informants. Informants were included in the sequence of the interviews

low for men alone with a significantly higher citations/ informant ratio (ANOVA, $\mathrm{df}=2, F=19.06, p<0.001$ ) and Shannon index (ANOVA, $\mathrm{df}=2, F=5.9, p=0.003$ ) for citations given by women versus men. The same holds for recipes (ANOVA, $\mathrm{df}=2, F=40.55, p<0.001$ and $\mathrm{df}=2, F=11.47, p<0.001$, respectively). Diversity parameters varied largely between villages (Table 2). For the Shannon index, the null hypothesis of the same mean for all villages was rejected for recipes (ANOVA, $\mathrm{df}=3, F=5.5, p=0.001$ ) but not for plant diversity (ANOVA, $\mathrm{df}=3, F=1.87, p=0.13$ ). With the exception of the Simpson index, the diversity parameters for the two villages Bemba II and Abing-Nkolemboula, which were located on minor gravel roads and were nearer to the Dja Reserve, were in general larger than for the two villages Doum and Assok, which were located on the major tar road and were further away from the Dja Reserve. The values for the Simpson index were the opposite, with the values for Doum and Assok being smaller than for Bemba II and Abing-Nkolemboula.

\section{WEP species, parts, and recipes}

The 88 plant species belonged to 61 genera and 43 families. Details on species, recipes, and citations are given in Table 3. Eight types of plant organs and exudates from organs of tubers, fruits, and leaves were the most used (Fig. 3a). Six types of use were quoted (Fig. 3b) with yams (Dioscorea spp.) being the most consumed, followed by fruits and ingredients. In general, tubers and yams were more often quoted as consumed in the cited recipes.

The most widely represented families were Dioscoreacea (21 species/436 citations/23 recipes), Euphorbiaceae (5/56/7), and Anonaceae (5/44/4). The most used WEP in terms of citations and recipes were: Baillonella toxisperma (112 citations/2 recipes), Afrostyrax lepidophyllus (108/8), Irvingia gabonensis (89/2), Poga oleosa (63/6), Dioscorea praehensilis (61/1), D. semperflorens (58/3), Gnetum africanum (57/1), Dioscorea mangenotiana (56/ 1), and Trichoscypha acuminata (51/2). The most cited recipes included yam tubers (Dioscorea praehensilis, $D$. mangenotiana, D. semperflorens, and D. munutiflor) as main courses, leaves of Gnetum africanum as vegetable, seeds of Baillonella toxisperma, bush mango Irvingia gabonensis, Afrostyrax lepidophillus, and Panda oleosa as ingredients, as well as the fruits of Baillonella toxisperma, Irvingia gaboneneis, and Trichoscypha acuminate.

\section{WEP access to the Baka community}

A total of 1505 citations included the distance of WEP collection from the village. The WEPs for $76.6 \%$ of citations were collected one or more kilometer away from the village compared to $22.5 \%$ close to the village. Except for Abing-Nkolemboula with 22.2\% of citations, interviewees from the three other villages collected WEP $1 \mathrm{~km}$ or more away from the village (Assok: 99.6\%, Bemba II: 100\%, Doum: 98.1\%). Collection distances are shown in Table 3. A total of 17 plants were exclusively

Table 1 Diversity indexes for WEP cited by women, men, and couples

\begin{tabular}{|c|c|c|c|c|c|c|c|c|}
\hline \multirow[t]{2}{*}{ Diversity parameters } & \multicolumn{2}{|c|}{ Women single } & \multicolumn{2}{|c|}{ Men single } & \multicolumn{2}{|c|}{ Women and men } & \multicolumn{2}{|l|}{ Total } \\
\hline & Plants & Recipes & Plants & Recipes & Plants & Recipes & Plants & Recipes \\
\hline Number of informants & 21 & & 46 & & 6 & & 73 & \\
\hline Number of citations (Ni) & 439 & & 894 & & 186 & & 1519 & \\
\hline Richness & 69 & 86 & 77 & 100 & 51 & 59 & 88 & 119 \\
\hline Density & 3.29 & 4.10 & 1.67 & 2.17 & 8.50 & 9.83 & 1.21 & 1.63 \\
\hline Shanon $(H)$ & 5.06 & 3.75 & 4.95 & 3.30 & 5.44 & 4.80 & 4.96 & 2.99 \\
\hline Pielou ( $€$ ) & 0.86 & 0.64 & 0.84 & 0.56 & 0.93 & 0.82 & 0.84 & 0.51 \\
\hline Simpson (D) & 0.03 & 0.01 & 0.04 & 0.01 & 0.03 & 0.02 & 0.03 & 0.01 \\
\hline
\end{tabular}


Table 2 Diversity indexes for WEP in the four study villages

\begin{tabular}{|c|c|c|c|c|c|c|c|c|}
\hline \multirow[t]{2}{*}{ Diversity parameters } & \multicolumn{2}{|l|}{ Assok } & \multicolumn{2}{|l|}{ Doum } & \multicolumn{2}{|l|}{ Bemba } & \multicolumn{2}{|c|}{ Nkolemboula } \\
\hline & Plants & Recipes & Plants & Recipes & Plants & Recipes & Plants & Recipes \\
\hline Number of informants (Inf) & 18 & & 16 & & 23 & & 16 & \\
\hline Number of quotations (Ni) & 259 & & 312 & & 505 & & 443 & \\
\hline Richness & 38 & 44 & 40 & 49 & 59 & 80 & 54 & 66 \\
\hline Density & 2.11 & 2.44 & 2.50 & 3.06 & 2.57 & 3.48 & 3.38 & 4.13 \\
\hline Shanon $(H)$ & 4.53 & 4.90 & 4.66 & 5.20 & 5.24 & 5.83 & 5.49 & 5.68 \\
\hline Pielou $(€)$ & 0.86 & 0.90 & 0.88 & 0.93 & 0.89 & 0.92 & 0.95 & 0.94 \\
\hline Simpson (D) & 0.06 & 0.04 & 0.05 & 0.03 & 0.03 & 0.02 & 0.03 & 0.02 \\
\hline
\end{tabular}

collected near villages, 35 plants one or more kilometer away and 35 plants at any distance.

Information on when plants were collected was obtained from 753 separate citations. Tubers were mainly harvested during the dry season (69.4\%), and fruits and seeds during the rainy season (82.3\%). Barks, exudates, and leaves were harvested during the whole year. A total of $44 \%$ of citations were collected during the dry seasons, 39\% during the wet season, and $17 \%$ throughout the year. The 753 citations with seasonal information involved 66 plants (Table 3), collected during the dry season $(14 \%)$, wet season (35\%), or both (51\%).

We recorded the daily weight of plants consumed in 27 households (Assok: 8, Doum: 19); a total of 99 measurements. As many as 27 different plant items were derived from agricultural plants $(n=13)$ and WEP $(n=$ 14). WEP included fruit $(1.7 \mathrm{~kg})$, tubers $(5.5 \mathrm{~kg})$, seeds $(5.4 \mathrm{~kg})$, and leaves $(0.02 \mathrm{~kg})$, and cultivated plants included fruit $(102.2 \mathrm{~kg})$, tubers (58.5), and leaves $(1.7 \mathrm{~kg})$ over the 2-week period. Musa paradisiaca (plantain: $51.6 \mathrm{~kg}$ ), Manihot esculenta (cassava: $49.5 \mathrm{~kg}$ ), Musa sapientum (banana: $32.0 \mathrm{~kg}$ ), and Elaeis guineensis (palm oil: $17.3 \mathrm{~kg}$ ) were the four main cultivated plants consumed, while yams $(5.5 \mathrm{~kg}$; 4 species) were the most harvested items among WEP (Fig. 4). The average number of products consumed per day in a household varied significantly between cultivated plants (mean $4.4 \pm 4.1$ $\mathrm{kg}$, median $3.2 \mathrm{~kg}, n=37$ ) and WEP (mean $1.0 \pm 1.2 \mathrm{~kg}$, median $0.5 \mathrm{~kg}, n=12$ ) with the difference being significant (Wilcoxon rank-sum test, $W=348, p=0.003$ ).

\section{Discussion}

Our results indicate that as many as 88 different plant species-including 14 putative, unidentified wild yam species-were consumed by the 73 interviewed Baka families. A total of 119 recipes included WEP. Despite this relatively large number of items identified in our study, the rarefaction analysis indicates that the number of species recorded is not likely to represent all the WEP diversity used in the study area. This is typical for studies where sampling is not conducted across all seasons, as indicated in an ethnobotanical survey in the Bamenda Highlands in western Cameroon [53]. Although we asked for information on WEP use throughout the year, it is likely that the use of some species elude the memory if they are only rarely consumed in a season other than when the interview was conducted. Except the 14 unidentified wild yam species, 17 WEP species had not been reported in any other ethnobotanical survey for the Baka [10]. A total of 51 plant usages were also unreported before.

The stated number of plants in our study is strikingly higher than the number reported in the grassland with some remaining patches of montane and submontane forests of the Lebialem highlands in southwest Cameroon, where only 26 WEP were documented from 300 respondents from 15 communities [55]. Our number of WEP is also double the number of species in the Bamenda highlands study, which was conducted at the same time of the year as our study but only reported 41 plant species by questioning 121 individuals [53]. Besides ecosystem-specific differences, there are two likely causes for the larger WEP diversity in our study site. First, our site south of Dja Faunal Reserve is in a better conservation state than the Lebialem highlands and the Bamenda highlands where the relatively high human population density has resulted in severe biodiversity degradation [53]. In our study area, there is some indication that WEP is over-exploited near settlements as the inhabitants of three out of four villages needed to travel more than $1 \mathrm{~km}$ for collection and harvesting. The distance between the location of harvested common species and the village indicates the scarcity of the resource. Ecosystem intactness might be reflected by the distance of villages to the Dja Faunal Reserve and the development of road infrastructure thus explaining why higher plant and recipe diversities were observed in the two more remote villages closer to the reserve. Second, Baka have inhabited the forested areas for millennia, relying on a hunter-gatherer lifestyle. Their extensive traditional knowledge of WEP is likely reflected in the high number of plants used. In contrast, the inhabitants of the 
Table 3 List of plant species, voucher number at the National Herbarium of Cameroon (YA)

\begin{tabular}{|c|c|c|c|c|c|c|c|c|c|}
\hline $\begin{array}{l}\text { Vernacular } \\
\text { name }\end{array}$ & Species & Family & Voucher \# & Season & Distance & Citations $(n)$ & $\begin{array}{l}\text { Plant } \\
\text { part }\end{array}$ & $\begin{array}{l}\text { Type of } \\
\text { usage }\end{array}$ & Literature \\
\hline 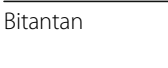 & $\begin{array}{l}\text { Abelmoschus esculentus (L.) } \\
\text { Moench }\end{array}$ & Malvaceae & Bil73 & $d+r$ & c & 1 & Leaf & Vegetable & Cameroon [47] \\
\hline Pouloue & $\begin{array}{l}\text { Adenia cissampeloides } \\
\text { (Planch. ex Hook.) Harms }\end{array}$ & Passifloraceae & Bil230 & r & c & 6 & Fruit & Fruit & Congo [22] \\
\hline \multirow{2}{*}{$\begin{array}{l}\text { Ndiyi na } \\
\text { gbeugbeu }\end{array}$} & \multirow{2}{*}{$\begin{array}{l}\text { Aframomum daniellii (Hook. f.) } \\
\text { K. Schum. }\end{array}$} & \multirow[t]{2}{*}{ Zingiberaceae } & \multirow[t]{2}{*}{ Bil2 } & \multirow[t]{2}{*}{$?$} & \multirow[t]{2}{*}{$f$} & \multirow[t]{2}{*}{3} & Leaf & Ingredient & \\
\hline & & & & & & & Fruit & Fruit & $\begin{array}{l}\text { Cameroon }[20,21,48,49], \\
\text { Congo [22] }\end{array}$ \\
\hline \multirow[t]{2}{*}{ Ndiyi na gdi } & \multirow{2}{*}{$\begin{array}{l}\text { Aframomum sulcatum (Oliv. } \\
\text { \& Hanb. ex Bak.) K. Schum. }\end{array}$} & \multirow[t]{2}{*}{ Zingiberaceae } & \multirow[t]{2}{*}{ Bet 15} & \multirow[t]{2}{*}{$?$} & \multirow[t]{2}{*}{ c } & \multirow[t]{2}{*}{3} & Leaf & Ingredient & \\
\hline & & & & & & & Fruit & Fruit & Cameroon [20] \\
\hline \multirow[t]{8}{*}{ Nguimba } & \multirow[t]{8}{*}{$\begin{array}{l}\text { Afrostyrax lepidophyllus } \\
\text { Mildbr. }\end{array}$} & \multirow[t]{8}{*}{ Huaceae } & \multirow[t]{8}{*}{ Nat 70} & \multirow[t]{8}{*}{$d+r$} & \multirow[t]{8}{*}{ Both } & \multirow[t]{8}{*}{108} & Bark & Ingredient & $\begin{array}{l}\text { Cameroon [20, 21, 50-52], } \\
\text { Congo [22] }\end{array}$ \\
\hline & & & & & & & Flower & Ingredient & \\
\hline & & & & & & & Fruit & Ingredient & \\
\hline & & & & & & & Leaf & Ingredient & \\
\hline & & & & & & & Root & Ingredient & \\
\hline & & & & & & & Root & Vegetable & \\
\hline & & & & & & & Seed & Ingredient & $\begin{array}{l}\text { Cameroon [10, 20, 51-53], } \\
\text { Congo [22] }\end{array}$ \\
\hline & & & & & & & Wood & Ingredient & \\
\hline Pwa kata & $\begin{array}{l}\text { Agelaea pentagyna } \\
\text { (Lam.) Baill. (syn: A. obliqua) }\end{array}$ & Connaraceae & Bet314 & $d+r$ & c & 8 & Leaf & Vegetable & \\
\hline Pwa Yando & Alchornea floribunda Müll. Arg. & Euphorbiaceae & Bil35 & $d+r$ & c & 11 & Leaf & Vegetable & \\
\hline Ngongou & $\begin{array}{l}\text { Anonidium mannii (Oliv.) } \\
\text { Engl. \& Diels }\end{array}$ & Annonaceae & Bil115 & $?$ & f & 16 & Fruit & Fruit & Cameroon [20] \\
\hline Mgbé & Antrocaryon klaineanum Pierre & Anacardiaceae & Bil287 & r & Both & 7 & Fruit & Fruit & $\begin{array}{l}\text { Cameroon [54], Congo } \\
{[22]}\end{array}$ \\
\hline \multirow[t]{2}{*}{ Mabé } & \multirow[t]{2}{*}{ Baillonella toxisperma Pierre } & \multirow[t]{2}{*}{ Sapotaceae } & \multirow[t]{2}{*}{ Bil75 } & r & Both & 112 & Fruit & Fruit & $\begin{array}{l}\text { Cameroon [20], Congo } \\
{[22]}\end{array}$ \\
\hline & & & & & & & Seed & Ingredient & $\begin{array}{l}\text { Cameroon [10, 20, 47, } \\
48,51,52] \text {, Congo [22] }\end{array}$ \\
\hline Fhandako & Calpocalyx dinklagei Harms & Mimosaceae & Bil146 & $d+r$ & Both & 5 & Fruit & Fruit & \\
\hline $\begin{array}{l}\text { Alamba na } \\
\text { bélé }\end{array}$ & Capsicum frutescens $\mathrm{L}$. & Solanaceae & Bil18 & $d+r$ & Both & 15 & Fruit & Ingredient & $\begin{array}{l}\text { Cameroon [47], Congo } \\
{[22]}\end{array}$ \\
\hline Motoubéloubé & Carapa procera DC. & Meliaceae & Bil136 & r & Both & 7 & Seed & Fruit & Congo [22] \\
\hline Monono & Carpolobia alba G. Don & Loganiaceae & Bil155 & r & c & 2 & Fruit & Fruit & $\begin{array}{l}\text { Cameroon }[20,48], \\
\text { Congo }[22]\end{array}$ \\
\hline Ligo & $\begin{array}{l}\text { Cola acuminata (P. Bwaterv.) } \\
\text { Schott \& Endl. }\end{array}$ & Sterculiaceae & Bil161 & r & Both & 3 & Seed & Fruit & $\begin{array}{l}\text { Cameroon [20, 21, 48, } \\
49,53], \text { Congo [22] }\end{array}$ \\
\hline Mécor & Cola rostrata K. Schum. & Sterculiaceae & Bil137 & r & Both & 6 & Seed & Fruit & Congo [22] \\
\hline Mengoumé & Coula edulis Baill. & Olacaceae & Bil 322 & $d+r$ & Both & 6 & Seed & Fruit & Cameroon $[20,47,48]$ \\
\hline Fawouaboka & $\begin{array}{l}\text { Desbordesia glaucescens } \\
\text { (Engl.) Tiegh. }\end{array}$ & Combretaceae & Bil130 & $?$ & $f$ & 2 & Seed & Fruit & \\
\hline Mgbii & Dicranolepis disticha Planch. & Thymeleaceae & Bil323 & $d+r$ & Both & 14 & Fruit & Fruit & \\
\hline & & & & & & & Leaf & Ingredient & \\
\hline & & & & & & & Tuber & Main & \\
\hline & & & & & & & Y-leaf & Ingredient & \\
\hline Kèkè & Dioscorea burkilliana Miège & Dioscoreaceae & Bil324 & $d+r$ & Both & 35 & Tuber & Main yam & $\begin{array}{l}\text { Cameroon }[10,17,51], \\
\text { Congo }[22]\end{array}$ \\
\hline Esssendé & Dioscorea hirtiflora Benth & Dioscoreaceae & Bil325 & $d+r$ & $f$ & 13 & Tuber & Main yam & \\
\hline Ba'a & $\begin{array}{l}\text { Dioscorea mangenotiana } \\
\text { Miège }\end{array}$ & Dioscoreaceae & Bil39 & $d+r$ & $f$ & 56 & Tuber & Main yam & $\begin{array}{l}\text { Cameroon }[17,51], \\
\text { Congo }[22]\end{array}$ \\
\hline Koukou & Dioscorea munutiflora Engl. & Dioscoreaceae & Bil295 & $d+r$ & Both & 42 & Tuber & Main yam & Congo [22] \\
\hline Saba & Dioscorea praehensilis Benth & Dioscoreaceae & Bil31 & $d+r$ & Both & 61 & Tuber & Main yam & Cameroon $[10,17,51]$, \\
\hline
\end{tabular}


Table 3 List of plant species, voucher number at the National Herbarium of Cameroon (YA) (Continued)

\begin{tabular}{|c|c|c|c|c|c|c|c|c|c|}
\hline $\begin{array}{l}\text { Vernacular } \\
\text { name }\end{array}$ & Species & Family & Voucher \# & Season & Distance & Citations $(n)$ & $\begin{array}{l}\text { Plant } \\
\text { part }\end{array}$ & $\begin{array}{l}\text { Type of } \\
\text { usage }\end{array}$ & Literature \\
\hline & & & & & & & & & Congo [22] \\
\hline \multirow[t]{3}{*}{ Essouma } & \multirow[t]{3}{*}{ Dioscorea semperflorens Uline } & \multirow[t]{3}{*}{ Dioscoreaceae } & \multirow[t]{3}{*}{ Bil 326} & \multirow[t]{3}{*}{$d+r$} & \multirow[t]{3}{*}{ Both } & \multirow[t]{3}{*}{58} & Leaf & Vegetable & \\
\hline & & & & & & & Tuber & Main yam & \multirow[t]{2}{*}{ Congo [22] } \\
\hline & & & & & & & Y-leaf & Vegetable & \\
\hline Baloko & $\begin{array}{l}\text { Dioscorea smilacifolia } \\
\text { De Wild. }\end{array}$ & Dioscoreaceae & Bil94 & $d+r$ & $f$ & 25 & Tuber & Main yam & $\begin{array}{l}\text { Cameroon [17], } \\
\text { Congo [22] }\end{array}$ \\
\hline Ndondo & Dioscorea sp1 & Dioscoreaceae & Bil309 & $d+r$ & $f$ & 32 & Tuber & Main yam & \\
\hline Booli & Dioscorea sp2 & Dioscoreaceae & Bil327 & $d$ & $f$ & 9 & Tuber & Main yam & \\
\hline Boto & Dioscorea sp3 & Dioscoreaceae & Bil328 & $d$ & f & 2 & Tuber & Main yam & \\
\hline Koubé & Dioscorea sp4 & Dioscoreaceae & Bil329 & r & f & 8 & Tuber & Main yam & \\
\hline Djakaka & Dioscorea sp5 & Dioscoreaceae & Bil330 & $d$ & f & 43 & Tuber & Main yam & \\
\hline Efhanguè & Dioscorea sp6 & Dioscoreaceae & Bil331 & $d$ & f & 34 & Tuber & Main yam & \\
\hline Ekorra & Dioscorea sp7 & Dioscoreaceae & Bil264 & $d$ & Both & 1 & Tuber & Main yam & \\
\hline Esopo & Dioscorea sp8 & Dioscoreaceae & Bil332 & $d+r$ & $f$ & 6 & Tuber & Main yam & \\
\hline Fhafhè & Dioscorea sp9 & Dioscoreaceae & Bil333 & $d+r$ & $f$ & 2 & Tuber & Main yam & \\
\hline Mbooto & Dioscorea sp10 & Dioscoreaceae & Bil334 & $d+r$ & $f$ & 2 & Tuber & Main yam & \\
\hline Moussokofandè & Dioscorea sp11 & Dioscoreaceae & Bil335 & $d+r$ & Both & 1 & Tuber & Main yam & \\
\hline Paper & Dioscorea sp12 & Dioscoreaceae & Bil336 & $d$ & $f$ & 2 & Tuber & Main yam & \\
\hline Scèndè & Dioscorea sp13 & Dioscoreaceae & Bil337 & $d$ & c & 1 & Tuber & Main yam & \\
\hline Diya & Dioscorea sp14 & Dioscoreaceae & Bil30 & $d$ & f & 3 & Tuber & Main yam & \\
\hline Bii & $\begin{array}{l}\text { Dioscoresphyllum cumminsii } \\
\text { (Stapf) Diels. }\end{array}$ & Menispermaceae & Bil338 & $d+r$ & $f$ & 23 & Tuber & Main & Congo [22] \\
\hline \multirow[t]{2}{*}{ Manjoubou } & \multirow{2}{*}{$\begin{array}{l}\text { Diplazium welwitschii } \\
\text { (Hooker) Diels }\end{array}$} & \multirow[t]{2}{*}{ Athyriaceae } & \multirow[t]{2}{*}{ Bil163 } & \multirow[t]{2}{*}{$d+r$} & \multirow[t]{2}{*}{ Both } & \multirow[t]{2}{*}{28} & Teaf & Vegetable & \multirow[t]{2}{*}{ Congo [22] } \\
\hline & & & & & & & Y-leaf & Vegetable & \\
\hline $\begin{array}{l}\text { Vin de palme } \\
\text { (Gobila) }\end{array}$ & Elaeis guineensis Jacq. & Arecaceae & Bil339 & $?$ & $?$ & 4 & $\begin{array}{l}\text { Exu- } \\
\text { date }\end{array}$ & Drink & Congo [22] \\
\hline \multirow[t]{4}{*}{ Tokomboli } & \multirow{4}{*}{$\begin{array}{l}\text { Eriocoelum macrocarpum } \\
\text { Gilg ex Radlk. }\end{array}$} & \multirow[t]{4}{*}{ Sapindaceae } & \multirow[t]{4}{*}{ Bil271 } & \multirow[t]{4}{*}{ r } & \multirow[t]{4}{*}{ Both } & \multirow[t]{4}{*}{38} & Fruit & Main & \multirow[t]{4}{*}{ Congo [22] } \\
\hline & & & & & & & Fruit & Fruit & \\
\hline & & & & & & & Seed & Main & \\
\hline & & & & & & & Seed & Fruit & \\
\hline Bambou & Gambeya africana (G. Don. & Sapotaceae & Bil256 & r & Both & 27 & Fruit & Fruit & \\
\hline & ex Bak.) Pier & & & & & & Seed & Fruit & Congo [22] \\
\hline Mpkom & Garcinia kola Heckel & Clusiaceae & Bil340 & $?$ & $f$ & 1 & Seed & Fruit & $\begin{array}{l}\text { Cameroon } \\
{[20,21,48,49,53],} \\
\text { Congo }[22]\end{array}$ \\
\hline Bemba & $\begin{array}{l}\text { Gilbertiodendron dewevrei } \\
\text { (De Wild.) Léonard }\end{array}$ & Caesalpiniaceae & Bil341 & r & c & 1 & Fruit & Fruit & Congo [22] \\
\hline Koko & Gnetum africanum Welw. & Gnetaceae & Bil147 & $d+r$ & Both & 57 & Leaf & Vegetable & $\begin{array}{l}\text { Cameroon } \\
{[10,20,21,47,} \\
48,50,53-56] \text {, } \\
\text { Congo [22], } \\
\text { Democratic Republic } \\
\text { of Congo [57] }\end{array}$ \\
\hline Yoloyolo & $\begin{array}{l}\text { Gymnanthemum amygdalinum } \\
\text { (Delile) Sch. Bip. ex Walp. }\end{array}$ & Asteraceae & Bil29 & $?$ & c & 1 & Leaf & Vegetable & \\
\hline Essang & Hibiscus sabdarifa $\mathrm{L}$ & Malvaceae & Bil342 & $?$ & c & 1 & Leaf & Ingredient & \\
\hline Mingaignai & Hua gaboni Pierre ex De & Huaceae & Bil343 & $?$ & $f$ & 4 & Bark & Ingredient & \\
\hline & & & & & & & Seed & Ingredient & \\
\hline Payo & Irvingia excelsa Mildbr. & Irvingiaceae & Bil160 & $d+r$ & Both & 48 & Fruit & Fruit & $\begin{array}{l}\text { Cameroon [10], } \\
\text { Congo [22] }\end{array}$ \\
\hline & & & & & & & Seed & Ingredient & \\
\hline Pféké & Irvingia gabonensis (Aub. & Irvingiaceae & Bil65 & $\mathrm{r}$ & Both & 89 & Fruit & Fruit & Cameroon [20], \\
\hline
\end{tabular}


Table 3 List of plant species, voucher number at the National Herbarium of Cameroon (YA) (Continued)

\begin{tabular}{|c|c|c|c|c|c|c|c|c|c|}
\hline $\begin{array}{l}\text { Vernacular } \\
\text { name }\end{array}$ & Species & Family & Voucher \# & Season & Distance & Citations $(n)$ & $\begin{array}{l}\text { Plant } \\
\text { part }\end{array}$ & $\begin{array}{l}\text { Type of } \\
\text { usage }\end{array}$ & Literature \\
\hline & Lec. Ex O'R.) Baill. & & & & & & & & Congo [22] \\
\hline & & & & & & & Seed & Ingredient & $\begin{array}{l}\text { Cameroon [10, 20, 21, } \\
47-54,56,58] \text {, Congo [22] }\end{array}$ \\
\hline Bokoko & Klainedoxa gabonensis Pierre & Irvingiaceae & Bil344 & $?$ & f & 3 & Seed & Fruit & Congo [22] \\
\hline Mapkwa & $\begin{array}{l}\text { Landolphia foretiana (Pierre } \\
\text { ex Jumelle) Pichon }\end{array}$ & Apocynaceae & Bil141 & $d+r$ & oth & 13 & Fruit & Fruit & Congo [22] \\
\hline Kwakata & Lasiodiscus sp. & Rhamnaceae & Bil345 & $?$ & $f$ & 12 & Leaf & Vegetable & \\
\hline Ngoka & Lophira alata Banks ex Gaertn. & Ochnaceae & Bil346 & $?$ & f & 1 & Fruit & Fruit & \\
\hline Ngongo & $\begin{array}{l}\text { Megaphrynium macrostachyum } \\
\text { (Benth.) Milne-Redh. }\end{array}$ & Maranthaceae & Bil347 & $?$ & f & 1 & Fruit & Fruit & $\begin{array}{l}\text { Cameroon [21], } \\
\text { Congo [22] }\end{array}$ \\
\hline Mbée & Momordica charantia L & Cucurbitaceae & Bil348 & r & c & 2 & Fruit & Fruit & \\
\hline Djingo & Monodora tenuifolia Benth & Annonaceae & Bil191 & $?$ & f & 18 & Seed & Ingredient & Cameroon $[20,47,49,53]$ \\
\hline \multirow[t]{2}{*}{ Kombo } & Musanga cecropioides R. Br. & Moraceae & Bil55 & r & Both & 8 & $\begin{array}{l}\text { Exu- } \\
\text { date }\end{array}$ & Drink & \\
\hline & & & & & & & Fruit & Fruit & Congo [22] \\
\hline Ngatta & Myrianthus arboreus P. Beauv. & Moraceae & Bil49 & r & Both & 12 & Fruit & Fruit & $\begin{array}{l}\text { Cameroon [20], } \\
\text { Congo }[22]\end{array}$ \\
\hline Mossé & $\begin{array}{l}\text { Nauclea diderrichii (De Wild. } \\
\text { \& T. Durand) Merr. }\end{array}$ & Rubiaceae & Bil134 & r & Both & 8 & Fruit & Fruit & Cameroon $[20,48]$ \\
\hline Nganako & Occimum gratissimum $\mathrm{L}$ & Lamiaceae & Bil349 & $d+r$ & c & 3 & Leaf & Ingredient & Cameroon $[47,53]$ \\
\hline Koungou & $\begin{array}{l}\text { Pachypodanthium barteri } \\
\text { (Benth.) Hutch. \& Dalz. }\end{array}$ & Annonaceae & Bil350 & r & Both & 2 & Fruit & Fruit & Congo [22] \\
\hline Kana & Panda oleosa Pierre & Pandaceae & Bil149 & $d+r$ & Both & 40 & Seed & Ingredient & $\begin{array}{l}\text { Cameroon }[10,20,48, \\
51,52] \text {, Congo [22] }\end{array}$ \\
\hline Léca-mgbi & $\begin{array}{l}\text { Pentaclethra macrophylla } \\
\text { Benth }\end{array}$ & $\begin{array}{l}\text { Leguminoseae- } \\
\text { Caesalpinioidaea }\end{array}$ & Bil66 & r & c & 1 & Fruit & Fruit & Cameroon [20] \\
\hline Mbalaka & Pentadiplandra brazzeana Bail. & Pentadiplandraceae & Bil80 & r & c & 14 & Seed & Ingredient & $\begin{array}{l}\text { Cameroon } \\
{[20,51,52,58] \text {, Congo [22] }}\end{array}$ \\
\hline Poivre & $\begin{array}{l}\text { Piper guineense Schum. \& } \\
\text { Thonn. }\end{array}$ & Piperaceae & Bil19 & $d+r$ & f & 9 & Fruit & Ingredient & $\begin{array}{l}\text { Cameroon [20, 21, 48, } \\
49,51-55], \text { Congo [22] }\end{array}$ \\
\hline \multirow[t]{6}{*}{ Po'o } & Poga oleosa Pierre & Anisophylleaceae & Bil57 & $d+r$ & Both & 63 & Fruit & Ingredient & Cameroon $[20,54]$ \\
\hline & & & & & & & Fruit & Main & \\
\hline & & & & & & & Fruit & Fruit & \\
\hline & & & & & & & Seed & Ingredient & \\
\hline & & & & & & & Seed & Main & \\
\hline & & & & & & & Seed & Fruit & \\
\hline Botounga & $\begin{array}{l}\text { Polyalthia suaveolens Engl. \& } \\
\text { Diels }\end{array}$ & Annonaceae & Bil114 & $d+r$ & c & 1 & Leaf & Vegetable & \\
\hline Ndémbélembé & $\begin{array}{l}\text { Potomorphe umbellata (L.) } \\
\text { Miq. (syn : Piper umbellatum) }\end{array}$ & Piperaceae & Bil154 & $d+r$ & c & 9 & Y-leaf & Vegetable & Cameroon [55] \\
\hline Péké & Raphia mombuttorum Drude & Arecaceae & Bil103 & $d+r$ & c & 6 & $\begin{array}{l}\text { Exu- } \\
\text { date }\end{array}$ & Drink & Cameroon [20] \\
\hline \multirow[t]{2}{*}{ Gobo } & \multirow{2}{*}{$\begin{array}{l}\text { Ricinodendron heudelotii } \\
\text { (Baill.) P. ex Heck. }\end{array}$} & \multirow[t]{2}{*}{ Euphorbiaceae } & \multirow[t]{2}{*}{ Bil69 } & \multirow[t]{2}{*}{$d+r$} & \multirow[t]{2}{*}{ Both } & \multirow[t]{2}{*}{19} & Fruit & Ingredient & \\
\hline & & & & & & & Seed & Ingredient & $\begin{array}{l}\text { Cameroon [10, 20, 21, } \\
47-53,56,58], \text { Congo [22] }\end{array}$ \\
\hline Moudongué & Salacia sp & Hypocrataceae & Bil351 & $?$ & Both & 20 & Fruit & Fruit & \\
\hline Libaba & $\begin{array}{l}\text { Santiria trimera (Oliv.) } \\
\text { Aubreville }\end{array}$ & Burseraceae & Bil121 & $d+r$ & Both & 14 & Fruit & Fruit & Congo [22] \\
\hline Ekoungou & Smilax anceps Wild. & Smilacaceae & Bil352 & $d$ & f & 5 & Tuber & Main & \\
\hline \multirow[t]{2}{*}{ Kasso } & \multirow[t]{2}{*}{$\begin{array}{l}\text { Tetracarpidium conophorum } \\
\text { (Müll. Arg.) Hutch. Et Dalz. }\end{array}$} & \multirow[t]{2}{*}{ Euphorbiaceae } & \multirow[t]{2}{*}{ Bil 353} & \multirow[t]{2}{*}{ ? } & \multirow[t]{2}{*}{$f$} & \multirow[t]{2}{*}{7} & Fruit & Fruit & $\begin{array}{l}\text { Cameroon [20], } \\
\text { Congo [22] }\end{array}$ \\
\hline & & & & & & & Seed & Fruit & \\
\hline Kpwo-ngo & $\begin{array}{l}\text { Tetracera alnifolia Willd. } \\
\text { Subsp. Alnifolia }\end{array}$ & Dilleniaceae & Bil105 & $?$ & f & 13 & $\begin{array}{l}\text { Exu- } \\
\text { date }\end{array}$ & Drink & Congo [22] \\
\hline
\end{tabular}


Table 3 List of plant species, voucher number at the National Herbarium of Cameroon (YA) (Continued)

\begin{tabular}{|c|c|c|c|c|c|c|c|c|c|}
\hline $\begin{array}{l}\text { Vernacular } \\
\text { name }\end{array}$ & Species & Family & Voucher \# & Season & Distance & Citations $(n)$ & $\begin{array}{l}\text { Plant } \\
\text { part }\end{array}$ & $\begin{array}{l}\text { Type of } \\
\text { usage }\end{array}$ & Literature \\
\hline Basapa & Tetracera sp & Dilleniaceae & Bil354 & $?$ & $f$ & 4 & $\begin{array}{l}\text { Exu- } \\
\text { date }\end{array}$ & Drink & \\
\hline Gwassafhè & Tetracera sp2 & Dilleniaceae & Bil355 & $?$ & $f$ & 1 & $\begin{array}{l}\text { Exu- } \\
\text { date }\end{array}$ & Drink & \\
\hline Djaga & $\begin{array}{l}\text { Tetrapleura tetraptera (Schum. } \\
\text { \& Thonn.) Taub. }\end{array}$ & Mimosaceae & Bil356 & $?$ & $f$ & 11 & Seed & Ingredient & $\begin{array}{l}\text { Cameroon [20, 21, } \\
47-49,51-53] \text {, Congo [22] }\end{array}$ \\
\hline Poussa & Treculia africana Desc. & Moraceae & Bil297 & $?$ & $f$ & 1 & Seed & Main & $\begin{array}{l}\text { Cameroon [20], } \\
\text { Congo [22] }\end{array}$ \\
\hline \multirow[t]{2}{*}{ Ngoyo } & $\begin{array}{l}\text { Trichoscypha acuminata } \\
\text { Engl. }\end{array}$ & Anacardiaceae & Bil249 & $r$ & Both & 51 & Fruit & Fruit & $\begin{array}{l}\text { Cameroon }[10,20], \\
\text { Congo }[22]\end{array}$ \\
\hline & & & & & & & Seed & Fruit & \\
\hline Mongolla & $\begin{array}{l}\text { Trichoscypha arborea } \\
\text { (A. Chev.) A. Chev. }\end{array}$ & Anacardiaceae & Bil274 & $r$ & Both & 28 & Fruit & Fruit & $\begin{array}{l}\text { Cameroon }[10,20], \\
\text { Congo }[22]\end{array}$ \\
\hline Séngui1 & $\begin{array}{l}\text { Uapaca paludosa Aubrév. } \\
\text { \& Léandri }\end{array}$ & Euphorbiaceae & Bil357 & $r$ & Both & 14 & Fruit & Fruit & \\
\hline Séngui2 & Uapaca guineensis & Euphorbiaceae & Bil50 & $?$ & $f$ & 5 & Fruit & Fruit & \\
\hline \multirow[t]{3}{*}{ Moundiyè } & Xylopia hypolampra Mildbr. & Annonaceae & Bil79 & $?$ & $f$ & 7 & Flower & Ingredient & \\
\hline & & & & & & & Leaf & Ingredient & \\
\hline & & & & & & & Seed & Ingredient & $\begin{array}{l}\text { Cameroon } \\
{[20,48,49,53]}\end{array}$ \\
\hline
\end{tabular}

Collection season ( $d$ dry season, $r$ rainy season, $d+r$ all year round, ? unknown), distance ( $n$ near, i.e. less than $1 \mathrm{~km}$ from village, $f$ far, both, ? unknown), number of citations, plant parts, usage, and occurrence in other sites as cited in the literature $[10,17,20-22,47-60]$

Bamenda highlands are mainly from the non-huntergatherer Tikares ethnic group, which settled the area in the eighteenth and nineteenth centuries [53].

Ingram and Schure [48] identified 30 "key" NTFP in Cameroon based on social, cultural, environmental, and economic values. Baka in our study use ten and eight species as WEP from the 17 highest scoring and $13 \mathrm{sec}-$ ond-highest scoring NTFP species, respectively, highlighting the biological, cultural, and economic importance of the biodiversity in the region. Highest scoring plants are those that are widely consumed and traded and/or are protected including the moabi (Baillonella toxisperma), cola nut (Cola acuminate), bitter cola (Garcinia kola, Gnetum africanum), bush mango (Irvingia gabonensis), bush pepper (Piper guineense), palm wine (Raphia mombuttorum, Ricinodendron heudelotii), aidon tree (Tetrapleura tetraptera and Xylopia hypolampra). The second-highest scoring plants are those that are widely traded or consumed, or have multiple uses or are protected or vulnerable. Used by the Baka are the following: Aframomum daniellii, cattlesticks (Carpolobia alba), noisette (Coula edulis), ironwood (Lophira alata, Megaphrynium macrostachyum), bilinga (Nauclea diderrichii), shea nut (Poga oleosa), and Trichoscypha arborea. All these edible species have been reported from surveys of Cameroonian markets [20]. Clark and Sunderland [61] list seven NTFP for Central Africa, five of which are WEP; all five were used in our study area: bush mango (Irvingia gabonensis), Gnetum africanum, Ricinodendron heudelotii, cola nut (Cola acuminate), and moabi (Baillonella toxisperma). The latter plus Irvingia gabonensis and Gnetum africanum are among the plants most cited for Cameroon [21, 48, 50].

The most species-rich genus was Dioscorea, the wild yams, with possibly 20 species. This includes Dioscorea mangenotiana, a vigorous annual climber that possesses a long-lived root which can attain as much as $60 \mathrm{~kg}$ in weight [15]. WEP are a major part of Baka cultural identity, and wild yams in particular play a specific role in their cosmology. Yams are considered as a link between humans, elephants, and the "jengi" spirit, because these three share this symbolic food [5]. For this reason, wild yams have been considered "Cultural Superfoods" [62], which also relates to the notion of a cultural keystone species [63]. The nutritional importance of wild yams is highlighted by the exploitation through "paracultivation," whereby growth of wild yams is managed in their natural environment, and overexploitation is largely avoided [15]. The relatively high number of wild yam species in our study concurs with those assumptions, but is in contrast to the observation by Gallois et al. [10]. Although they report that Baka prefer wild yam when readily available, they seem not to be easily available in their study area, explaining the relative low consumption of wild yams observed there. Similarly, Hirai et al. [51] report only three species ( $D$. mangenotiana, D. burkilliana, D. praehensilis) at the northern periphery of the Boumba-Bek National Park 

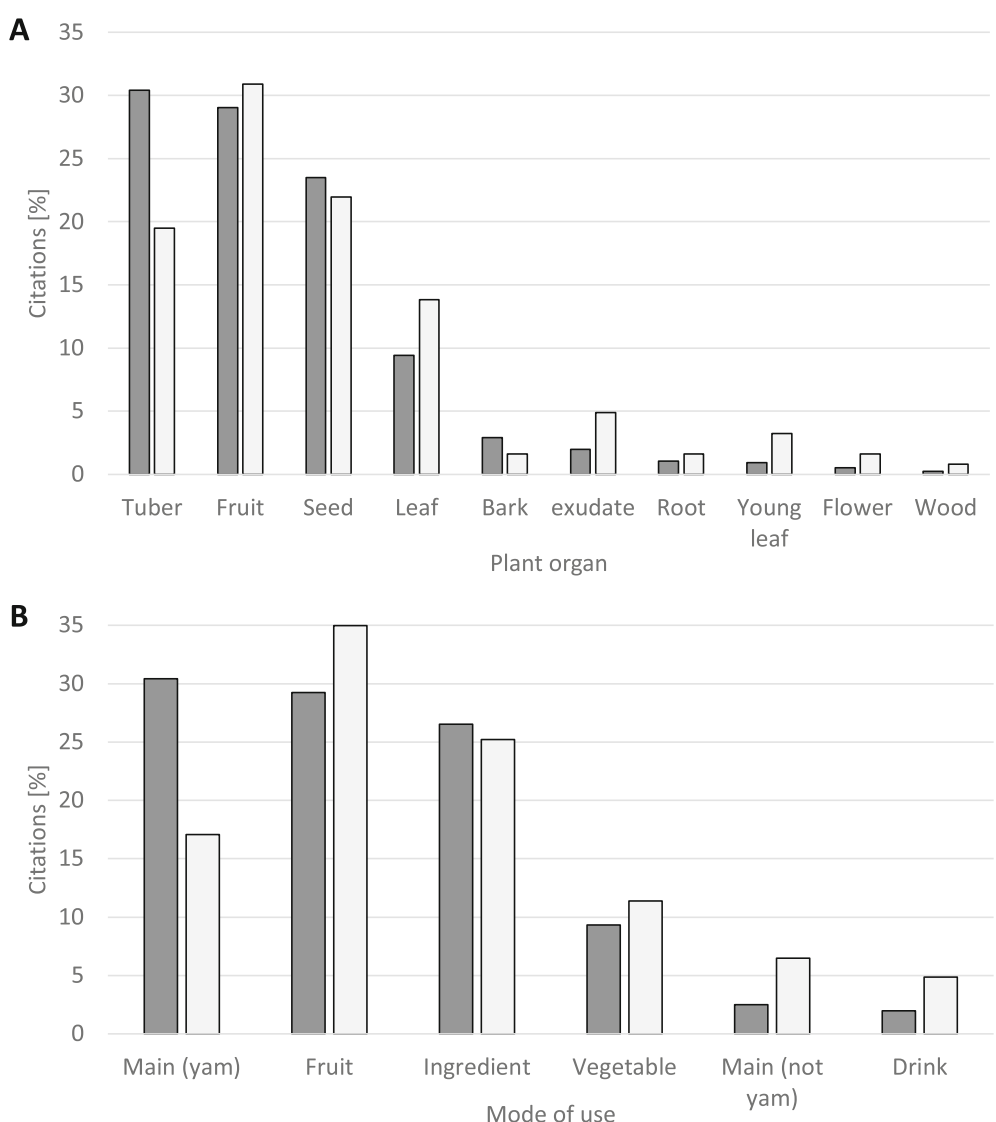

Fig. 3 Plant organs (a) and usage (b). Citations are quotations (dark) and recipes (light)

in the East Region of Cameroon. Wild yams store starchy reserves in aerial or underground tubers and are the most important source of carbohydrates for many hunter-gatherers of African forests [15]. Cameroon has the highest yam diversity in Africa with 17 probable species [64], followed by Gabon [65] and Congo Brazzaville [66] with 12 species each, Central African Republic with 11 species [67], and Congo Kinshasa with 9 species [15]. We could only identify six species though there were 14 putative species, which the Baka distinguish with separate names. These presumed yam species remain unidentified and should be a prime target for future work to establish whether there are undescribed species in our study area.

Plant foods other than wild yams are also important sources of macro- and micronutrients and energy for millions of people in the Congo Basin. Enquiries conducted in different regions in Cameroon [21, 49, 53, 59], Côte d'Ivoire [68], and in the Democratic Republic of Congo [57] revealed a high proportion of WEP fruits and seeds. The importance of fruits or seeds is linked to their high nutritive value and also to the production and long-term storage of derived products (oils for example). Edible wild fruits play a key role in the well-being of rural communities in developing countries in Africa and elsewhere, since they replace domestic vegetables during shortage periods (e.g., [69]). The daily consumption of some of these fruits may offer protection against some ailments and oxidative stress [70]. The main fatty acids of Baillonella toxisperma oils are oleic, stearic, and palmitic acids. The fact that the biochemical characteristics and fatty acid profile are comparable to common vegetable oils shows that the $B$. toxisperma oil is a potential source of valuable oil which might be used for edible, cosmetic, pharmaceutical and other industrial applications [71]. Etong and Mustapha [72] found that the oil of the bush mango Irvingia gabonensis contains six major fatty acids. Oil extracted can be useful both domestically and industrially. Among vegetables, the widely used species of the Gnetum genus are rich in proteins, minerals, and amino acids [73]. Among spices, Afrostyrax lepidophyllus has antioxidant, anti-inflammatory, and anti-xanthine oxidase activity [74]. The raphiales and palm trees are known by all the people of the Congo Basin as plants producing wines [22]. However, for the majority of species quoted in this study, especially those not listed as "key" NTFP in Cameroon by Ingram and Schure [48], the main nutritional and pharmacological remain undocumented. 


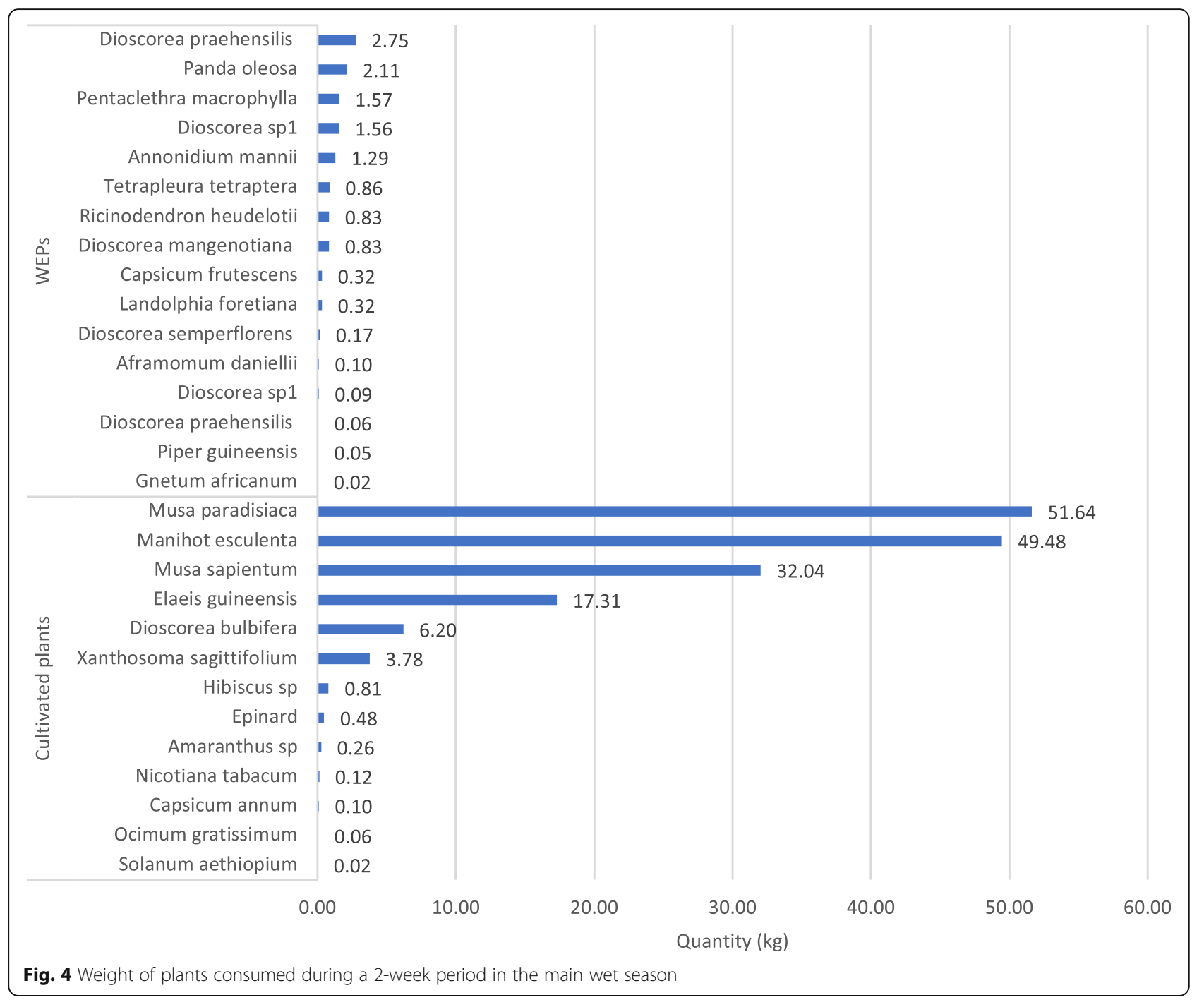

While the Baka use of WEP during the whole year is expected to be significant, our 2-week survey of plants used revealed only 14 WEP species were exploited during that time. This relatively small number of WEP is surprising since the quantitative survey was conducted during the major rainy season, when mobility into the forest for hunting and gathering is highest. On the other hand, a low diversity of wild plants was also observed in the diet of Baka in the same region of Cameroon [10] and by other hunter-gatherers in the Congo Basin [75, 76]. For example, Gallois et al. [10] conducted food recalls for the preceding $24 \mathrm{~h}$ of 536 individuals and revealed 14 different WEP. Thus, quantitative surveys of WEP use need to be performed during the whole year, as we have done in this study. During our 2-week food quantification, Baka heavily relied on cultivated starchy foods (cassava, plantain) from their own agricultural production. Although there was a large variance between households, the total weight of consumed cultivated plants exceeded the weight of WEP threefold. Plantain, cassava, banana, and oil palm are the four main cultivated plants used, while wild yams (4 species) represent the most harvested products among the WEP. A similar bias toward cultivated food was observed by Gallois et al. [10]. In their study, starchy foods were cited in 93\% of dietary recalls.

Among the BaYaka Pygmies from Congo, knowledge of WEP is widely shared among people regardless of relatedness, while knowledge of medicinal plants is mainly kept between spouses and relatives [13]. It is, therefore, surprising to find such strong sex-specific differences in the information given by men and women in our study site. About twice as many men reported WEP details than women. We noted that Baka women talk scarcely when they are accompanied by their husbands. But when they have an opportunity to be alone Baka women were much more open and provided more information than men on the same subject (high diversity of usages), 
which explains the higher information densities of plants and recipes, the higher values of the Shannon and Pielou indexes for plants and recipes and the weak values of the Simpson index for plants. All these findings highlight the importance of gathering information from all members of a given family during ethnobotanical surveys.

\section{Conclusions}

Surveys carried out among Baka people living south of the Dja Biosphere Reserve revealed 88 edible plants species including 14 putative but not identified wild yam species (genus Dioscorea). This genus was with six identified and 14 putative species the most species-rich genus in the study, emphasizing their nutritional and cultural importance for Baka. Compared to the Bamenda Highlands in western Cameroon, the Baka WEP diversity was more than double. Excluding the 14 unidentified wild yam species 17 WEP species have not been reported in any other ethnobotanical survey including on Baka [10]. The importance of the study area for WEP diversity is also highlighted by the fact that 18 out of the 30 "key" NTFP in Cameroon [48] were quoted by Baka. The increasing influence of market economies on the lifestyle of hunter-gatherers since sedentarization from the 1950s onwards is exemplified by the high proportion of starchy food in daily nutritional intake observed here and elsewhere [10]. Baka still harvest and use a wide variety of WEP, giving the opportunity to further document Baka's knowledge of WEP especially as biological resources and indigenous knowledge are diminishing with high destruction and a growing disinterest among the younger generation [53]. Fostering this knowledge will be important for sustainable development and achieving food security.

\section{Supplementary information}

Supplementary information accompanies this paper at https://doi.org/10. 1186/s13002-020-00413-0.

Additional file 1. : Questionnaire pour les produits forestiers non ligneux (PFNL) utilises dans l'arrondissement de mintom: les plantes alimentaires.

\section{Acknowledgements}

We are most grateful for CIFOR's Director in Cameroon, Dr. Richard Eba'a Atyi for his constant encouragement and advice. We are grateful to the people of the study area for contributing to this research as well as for their warm hospitality. We thank the forest technicians Mm. Selema and Djendj Miasse and the botanists Dr. Barthelemy Tchengue and Mr Eric Ngansop for their assistance in identifying trees in the field and plants in the National Herbarium, respectively. Two anonymous reviewers provided constructive and helpful comments.

\section{Authors' contributions}

Conceptualization, designing the study and data analysis: JLB, JEF. Data collection and analysis: PEBF, NAN, OFN, STW, EAM, GRB, RO. Writing: JLB, SMF, JEF. All authors read and approved the final manuscript.

\section{Funding}

Funding was provided by the UK Government's Darwin Initiative (Project no. 24029). This study was also supported by USAID as part of the Bushmeat Research Initiative of the CGIAR research program on Forests, Trees, and Agroforestry. Additional funding was provided by the SIFCO, through CAFR AM. No funding body has no direct role in the design of the study and collection, analysis, and interpretation of data and in writing the manuscript.

Availability of data and materials

Plant specimens were deposited in the National Herbarium of Cameroon, Yaoundé.

Ethics approval and consent to participate

Before conducting interviews, prior informed consent was obtained from all participants. No formal ethics approval was required.

\section{Consent for publication}

Not applicable

\section{Competing interests}

The authors declare that they have no competing interests.

\section{Author details}

${ }^{1}$ Department of Plant Biology, Faculty of Sciences, University of Douala, BP 24157 Douala, Cameroon. 'Zerca y Lejos ONGD, c/Sambara 128, 28027 Madrid, Spain. ${ }^{3}$ Department of Natural Sciences, School of Science and the Environment, Manchester Metropolitan University, Manchester M1 5GD, UK ${ }^{4}$ Center for International Forestry Research (CIFOR), CIFOR Headquarters, Bogor 16115, Indonesia. ${ }^{5}$ Nature Heritage, St. Lawrence, Jersey, Channel Islands, UK.

Received: 13 July 2020 Accepted: 1 October 2020

Published online: 22 October 2020

\section{References}

1. Turner NJ, Łuczaj ŁJ, Migliorini P, Pieroni A, Dreon AL, Sacchetti LE, et al. Edible and tended wild plants, traditional ecological knowledge and agroecology. Crit Rev Plant Sci. 2011;30:198-225.

2. Grivetti LE, Ogle BM. Value of traditional foods in meeting macro- and micronutrient needs: the wild plant connection. Nutr Res Rev. 2000;13:3146.

3. Vira B, Wildburger C, Mansourian S. Forests, trees and landscapes for food security and nutrition. A global assessment report. In: Forests and food: addressing hunger and nutrition across sustainable landscapes. Vienna: International Union of Forest Research Organizations; 2015. p. 172.

4. Asprilla-Perea J, Díaz-Puente JM. Importance of wild foods to household food security in tropical forest areas. Food Sec. 2019:11:15-22.

5. Joiris $V$. The mask that is hungry for yams: ethno-ecology of Dioscorea mangenotiana among the Baka, Cameroon. In: Hladik CM, Hladik A, Linares OF, Pagezy H, Semple AT, Hadley M, editors. Tropical forests, people and food: biocultural interactions and applications to development. Paris, France: Parthenon Unesco; 1993. p. 633-41.

6. Kuhnlein HV, Erasmus B, Spigelski D, FAO. Editors. Indigenous peoples' food systems: the many dimensions of culture, diversity and environment for nutrition and health. Reprinted. Food and Agriculture Organization of the United Nations: Rome; 2009.

7. Headland TN, Blood D. What place for hunter-gatherers in millennium three? [internet]. SIL International and the International Museum of Cultures: Dallas, TX; 2002. Available from: https://books.google.cl/books?id=mEd5 AAAAMAAJ.

8. Reyes-García V, Powell B, Díaz-Reviriego I, Fernández-Llamazares Á, Gallois S, Gueze M. Dietary transitions among three contemporary hunter-gatherers across the tropics. Food Security. 2019;11:109-22.

9. Hagino I, Sato H, Yamauchi T. The demographic characteristics and nutritional status for a hunter-gatherer society with social transitions in southeastern Cameroon. African study monographs. 2014;Supplementary issue:45-57.

10. Gallois S, Heger T, van Andel T, Sonké B, Henry AG. From bush mangoes to bouillon cubes: wild plants and diet among the Baka, foragerhorticulturalists from Southeast Cameroon. Econ Bot [Internet]. 2020 [cited 
2020 Mar 13]; Available from: http://link.springer.com/10.1007/s12231-02009489-x.

11. Bahuchet S, McKey D, de Garine I. Wild yams revisited: is independence from agriculture possible for rain forest hunter-gatherers? Hum Ecol. 1991; 19:213-43.

12. Tyukavina A, Hansen MC, Potapov P, Parker D, Okpa C, Stehman SV, et al. Congo Basin forest loss dominated by increasing smallholder clearing. Sci Adv. 2018;4:eaat2993.

13. Salali GD, Chaudhary N, Thompson J, Grace OM, van der Burgt XM, Dyble $M$, et al. Knowledge-sharing networks in hunter-gatherers and the evolution of cumulative culture. Curr Biol. Elsevier; 2016;26:2516-2521.

14. Hladik A, Dounias E. Wild yams of the African forest as potential food resources. In: Hladik CM, Hladik A, Linares OF, Pagezy H, Semple A, Hadley $M$, editors. Biocultural interactions and applications to development [internet]. Paris: UNESCO; 1993 [cited 2020 May 2]. p. 163-76. Available from: https://onlinelibrary.wiley.com/doi/abs/10.2134/jeq1994.0047242500230006 0036x.

15. Dounias E. The management of wild yam tubers by the Baka Pygmies in Southern Cameroon. African study monographs. 2001;Suppl. 26:135-56.

16. Yasuoka $\mathrm{H}$. The variety of forest vegetations in South-eastern Cameroon, with special reference to the availability of wild yams for the forest huntergatherers. African Study Monographs. 2009;30:89-119.

17. Yasuoka H. Dense wild yam patches established by hunter-gatherer camps: beyond the wild yam question, toward the historical ecology of rainforests. Hum Ecol. 2013;41:465-75.

18. Sato H, Kawamura K, Hayashi K, Inai H, Yamauchi T. Addressing the wild yam question: how Baka hunter-gatherers acted and lived during two controlled foraging trips in the tropical rainforest of southeastern Cameroon. AS. 2012;120:129-49.

19. Tanno T. Plant utilization of the Mbuti pygmies: with special reference to their material culture and use of wild vegetable foods. African Study Monographs. The Research Committee for African Area Studies, Kyoto University; 1981;1:1-53.

20. Betti JL. Plan d'action/Stratégie pour une meilleure collecte des données statistiques sur les Produits Forestiers Non Ligneux au Cameroun et recommandations pour les pays de la COMIFAC. Yaoundé Cameroun: COMIFAC; 2007 p. 180. Report No.: GCP/RAF/398/GER.

21. Betti JL, Ngankoué CM, Dibong SD, Singa AE. Etude ethnobotanique des plantes alimentaires spontanées vendues dans les marchés de Yaoundé, Cameroun. International journal of biological and chemical sciences. Ivyspring International Publisher. 2016;10:1678-93.

22. Betti JL, Kourogue RL, Achuo Mbong F, Billong Fils PE, Njimbam Njukouyou OF. Diversity in the usages of edible wild plants by the Baka and Bakwélé in the periphery of the Tala Tala Forest Management Unit, North Congo. Ethnobot Res App [Internet]. 2020 [cited 2020 May 13];19. Available from: http://journals.sfu.ca/era/index.php/era/article/view/1781.

23. Hattori S. Utilization of Marantaceae plants by the Baka hunter-gatherers in southeastern Cameroon. African Study Monographs. 2006;Suppl. 33:29-48.

24. Bahuchet S. Cultural diversity of African pygmies. In: Hewlett BS, editor. Hunter-gatherers of the Congo Basin: cultures, histories and biology of African pygmies. New Brunswick, NJ: Transaction Publishers; 2014. p. 1-29.

25. Hewlett BS, editor. Hunter-gatherers of the Congo Basin: cultures, histories and biology of African pygmies. New Brunswick, NJ: Transaction Publishers; 2014.

26. Leclerc C. L'adoption de l'agriculture chez les Pygmées Baka du Cameroun. Editions Quae; 2012

27. Froment A. Human biology and the health of African rainforest inhabitants. In: Hunter-gatherers of the Congo basin. New Brunswick, New Jersey: Transaction Publishers; 2014. p. 117-64.

28. Pemunta NV. Fortress conservation, wildlife legislation and the Baka pygmies of Southeast Cameroon. GeoJournal. Springer; 2019;84:1035-1055.

29. Yasuoka $\mathrm{H}$. Fledging agriculturalists? Rethinking the adoption of cultivation by the Baka hunter-gatherers. African Study Monographs. 2012;43:85-114.

30. Dounias E, Froment A. When forest-based hunter-gatherers become sedentary: consequences for diet and health. Unasylva. 2006;57:8.

31. Zerca y Lejos. Soberanía alimentaria y medios de vida (Baka food security) [Internet]. 2020 [cited 2020 Apr 20]. Available from: https://zercaylejos.org/ proyectos/soberania-alimentaria/.

32. Zerca y Lejos. Educación [Internet]. 2020 [cited 2020 Apr 20]. Available from: https://zercaylejos.org/proyectos/educacion/.
33. Duda R. Ethnoecology of hunting in an empty forest: practices, local perceptions and social change among the Baka (Cameroon) [Ph.D. dissertation]. [Barcelona, Spain]: Universitat Autonoma de Barcelona; 2017.

34. World Weather Online. Djoum Monthly Climate Averages [Internet]. 2020 [cited 2020 Apr 20]. Available from: https://www.worldweatheronline.com/ djoum-weather-averages/sud/cm.aspx.

35. Letouzey R. Notice phytogéographique du Cameroun au 1:500000. Toulouse, France: Institut de la Carte Internationale de la végétation; 1985.

36. Social Research Association. Social research association, ethical guidelines. London: Social Research Association; 2003.

37. Betti JL. Usages traditionnels et vulnérabilité des plantes médicinales dans la réserve de biosphère du Dja, Cameroun. [Thèse Doc]. [Univ. Libre de Bruxelles]; 2001.

38. Letouzey R. Contribution de la botanique au problème d'une éventuelle langue pygmée. Paris: Selaf; 1976.

39. Conservatoire et Jardin botaniques. Base de données des plantes d'Afrique [Internet]. 2020 [cited 2020 May 12]. Available from: https://www.ville-ge.ch/ musinfo/bd/cjb/africa/recherche.php?langue=fr.

40. Plant List. Plant list - a working list of all plant species [Internet]. 2020 [cited 2020 May 12]. Available from: http://www.theplantlist.org/tpl1.1/search?q=

41.PI@ntUse. Pl@ntUse [Internet]. 2020. Available from: https://uses.plantnetproject.org/fr/.

42. Peet RK. The measurement of species diversity. Annual review of ecology and systematics. JSTOR. 1974:285-307.

43. Shannon CE, Weaver W. The mathematical theory of communication: University of illinois Press; 1949.

44. Simpson EH. Measurement of diversity. Nature. 1949;163:688.

45. Pielou EC. An introduction to mathematical ecology. An introduction to mathematical ecology. New York, USA, Wiley-Inter-science; 1969;

46. R Foundation for Statistical Computing. R [Internet]. 2018. Available from: https://www.r-project.org.

47. Nnanga F, Priso J, Dongmo A, Din N. Ethnobotanical study of plant non timber forest products in the coastal area of Cameroon: cases of Yabassi and Mouanko. J Biodiversity Environ Sci. 2017;10:225-39.

48. Ingram V, Schure J. Review of non timber forest products (NTFPs) in Central Africa. Cameroon, CIFOR, Yaounde, Cameroon. 2010.

49. Dibong SD, Mpondo EM, Ngoye A, Priso RJ. Inventory and biodiversity of species edible wild fruits sold in the markets of Douala, Cameroon. Int J Appl Biol Pharm Technol. 2011;2:303-11.

50. Sneyd L. Wild food, prices, diets and development: sustainability and food security in urban Cameroon. Sustainability. 2013;5:4728-59.

51. Hirai M. Agricultural land use, collection and sales of non-timber forest products in the Agroforest Zone in Southeastern Cameroon. The Research Committee for African Area Studies, Kyoto University; 2014;.

52. Ngansop TM, Biye EH, Fongnzossie FE, Forbi PF, Chimi DC. Using transect sampling to determine the distribution of some key non-timber forest products across habitat types near Boumba-Bek National Park, south-East Cameroon. BMC Ecol. 2019;19:3.

53. Fongnzossie EF, Nyangono CFB, Biwole AB, Ebai PNB, Ndifongwa NB, Motove J, et al. Wild edible plants and mushrooms of the Bamenda highlands in Cameroon: ethnobotanical assessment and potentials for enhancing food security. J Ethnobiol Ethnomedicine. 2020;16:12.

54. Rist L, Shanley P, Sunderland T, Sheil D, Ndoye O, Liswanti N, et al. The impacts of selective logging on non-timber forest products of livelihood importance. For Ecol Manag. 2012;268:57-69.

55. Ngone Abwe M, Monah NL, Mih AM. Survey of wild vegetables in the Lebialem highlands of South Western Cameroon. J Plant Sci. 2016;4:172-84.

56. Tieguhong JC, Grouwels S, Ndoye O, Mala AW, Sakam IF, Useni M, et al. Financial status of small and medium scale enterprises based on non-wood forest products (NWFP) in Central Africa. Forest Policy Econ. 2012;20:112-9.

57. Mutambwe Shango. Revue Nationale sur les Produits Forestiers non Ligneux (PFNL). Cas de la République Démocratique du Congo. Establishment of Forestry Research Network for ACP Countries (FORENET); 2010.

58. Mala WA, Tieguhong JC, Ndoye O, Grouwels S, Betti JL. Collective action and promotion of forest based associations on non-wood forest products in Cameroon. Development in Practice. Taylor \& Francis; 2012;22:1122-34.

59. Priso RJ, Flore NJ, Jacques E, Ndongo D, Akoa A. Les produits forestiers non ligneux d'origine végétale: valeur et importance dans quelques marchés de la région du Littoral-Cameroun. J Appl Biosci. 2011;40:2715-26.

60. Betti JL. Medicinal plants sold in Yaounde markets, Cameroon. Afr Study Monographs. 2002;23:47-64. 
61. Clark LE, Sunderland TC. The key non-timber forest products of Central Africa: state of the knowledge. Washington DC: US Agency for International Development (USAID); 2004.

62. Dounias E. Sauvage Ou Cultivé? La paraculture des ignames sauvages par les pygmées Baka du Cameroun. In: Hladik CM, Hladik A, Pagezy H, Linares OF, GJA K, Froment A, editors. I'Alimentation en forêt tropicale: interactions bioculturelles et perspectives de développement. Paris, France: UNESCO; 1996. p. 939-60.

63. Garibaldi A, Turner N. Cultural keystone species: implications for ecological conservation and restoration. Ecol Soc. 2004;9.

64. Hladik A, Dounias E. Les ignames spontanées des forets africaines, plantes a tubercules comestibles. In: Hladik CM, Hladik A, Pagezy H, Linares OF, Koppert GJA, Froment A, editors. Tropical forests, people and food: biocultural interactions and applications to development. Paris: Parthenon Unesco; 1996. p. 275-294.

65. Hladik A, Bahuchet S, Ducatillion C, Hladik CM. Les plantes a tubercules de la foret dense d'Afrique centrale. Revue d'Ecologie (Terre et Vie). 1994;39: 249-90.

66. Nkounkou JS, Lejoly J, Geerinck D. Les Dioscoreaceae du Congo. Fragm Flor Geobot. 1993;2:139-82

67. La BS. Rencontre des agriculteurs. Les Pygmées parmi les peuples d'Afrique Centrale. Paris: Peeters-SELAF; 1993.

68. Gautier-Beguin D. Etude ethnobotanique des plantes de cueillettes à utilisation alimentaire dans un village au Sud du V-Baoulé (Côte d'Ivoire centrale) [Thèse de Doctorat ès Sciences Techniques, mention biologique]. [Genève]: Université de Genève; 1992.

69. Somnasang P, Moreno-Black G. Knowing, gathering and eating: knowledge and attitudes about wild food in an Isan village in northeastern Thailand. J Ethnobiol. 2000;20:197-216.

70. Fungo R, Muyonga J, Kaaya A, Okia C, Tieguhong JC, Baidu-Forson JJ. Nutrients and bioactive compounds content of Baillonella toxisperma, Trichoscypha abut and Pentaclethra macrophylla from Cameroon. Food Sci Nutr. 2015;3:292-301.

71. Fungo R, Ngondi J, Muyonga JH, Tchatat M, Odjo S, Tieguhong J. Physicochemical characteristics and fatty acid profile of Baillonella toxisperma Pierre traditionally extracted edible oil from Cameroon forests. Afr J Food Agric Nutr Dev. 2017;17:12758-74

72. Etong DI, Mustapha AO, Taleat AA. Physicochemical properties and fatty acid composition of dikanut (IIvingia gabonensis) seed oil. Res J Chem Sci. 2014;4:70-4

73. Fasuyi AO. Nutritional potentials of some tropical vegetable leaf meals: chemical characterization and functional properties. Afr J Biotechnol. 2006;5:49-53.

74. Namkona AF, Bolevane OSF, Moustapha F, Worowounga X, Ngaissona P, Koane JN, et al. Biological activities and phytochemical analysis of extracts Afrostyrax lepidophyllus Mildbr, seeds. J Phytopharmacology. 2017;6:102-6.

75. Termote C, Everaert G, Bwama Meyi M, Dhed'a Djailo B, Van Damme P. Wild edible plant markets in Kisangani. Democratic Republic of Congo. Hum Ecol. 2012:40:269-85.

76. Ichikawa M. Déterminismes écologiques et culturels des choix alimentaires des chasseurscueilleurs Mbuti du Zaire. In: Hladik CM, Hladik A, Pagezy H, Linares OF, GJA K, Froment A, editors. I'Alimentation en forêt tropicale: interactions bioculturelles et perspectives de développement. Paris, France: UNESCO; 1996. p. 759-70.

\section{Publisher's Note}

Springer Nature remains neutral with regard to jurisdictional claims in published maps and institutional affiliations.

Ready to submit your research? Choose BMC and benefit from:

- fast, convenient online submission

- thorough peer review by experienced researchers in your field

- rapid publication on acceptance

- support for research data, including large and complex data types

- gold Open Access which fosters wider collaboration and increased citations

- maximum visibility for your research: over $100 \mathrm{M}$ website views per year

At BMC, research is always in progress.

Learn more biomedcentral.com/submissions 